\title{
Resin Content and Board Density Dependent Mechanical Properties of One-Layer Particleboard Made from Willow (Salix viminalis)
}

\section{Mehanička svojstva jednoslojne ploče iverice od drva vrbe (Salix viminalis) u ovisnosti o sadržaju ljepila i gustoći ploče}

\author{
Original scientific paper $\bullet$ Izvorni znanstveni rad \\ Received-prispjelo: 14. 1. 2015. \\ Accepted-prihvaćeno: 5. 5. 2016. \\ UDK: $630 * 863.21 ; 630 * 812.42 ; 674.031 .623 .229$ \\ doi:10.5552/drind.2016.1502
}

\begin{abstract}
The paper presents the results of studies on the mechanical properties of one-layer particleboards made from willow (Salix viminalis). Since the particleboards were to simulate the core layer of typical furniture three-layer particleboards, they were made from coarse particles of the size from 1 to $4 \mathrm{~mm}$ using urea-formaldehyde resin as a binder. The effects of board density and resin content were evaluated. Three levels of resin content: 8,9 and $10 \%$, and board density: $0.57,0.60$ and $0.63 \mathrm{~g} / \mathrm{cm}^{3}$, were assumed. The effects of both factors, for their assumed ranges of variation, on the mechanical properties of particleboard were statistically significant. The modulus of elasticity (MOE), modulus of rupture (MOR), internal bond (IB) and screw holding strength (SHS) were determined. The effect of board density on MOE and MOR was greater than that of resin content, whereas the effect of board density on IB and SHS was less than that of resin content.
\end{abstract}

Key words: particleboard, Salix viminalis, mechanical properties, resin content, density

SAŽETAK • U radu su prikazani rezultati istraživanja mehaničkih svojstava jednoslojne ploče iverice izrađene od drva vrbe (Salix viminalis). Kako bi se dobile iverice koje simuliraju srednji sloj tipične troslojne ploče za izradu namještaja, iverice su izrađene od drvnih čestica veličine od 1 do $4 \mathrm{~mm}$, uz primjenu urea-formaldehidnog ljepila kao veziva. Procijenjen je utjecaj gustoće ploče i sadržaja ljepila na mehanička svojstva ploča. Istražene su tri razine sadržaja ljepila: 8,9 i $10 \%$, te tri gustoće ploče: $0,57,0,60$ i $0,63 \mathrm{~g} / \mathrm{cm}^{3}$. Utjecaj sadržaja ljepila $i$ gustoće na mehanička svojstva ploča statistički je značajan. Istraživana su ova mehanička svojstva ploča: modul elastičnosti (MOE), modul loma (MOR), unutrašnja čvrstoća vezanja (IB) i čvrstoća držanja vijaka (SHS). Gustoća ploče imala je veći utjecaj na MOE i MOR nego sadržaj ljepila, dok je utjecaj gustoće ploče na IB i SHS bio manji od utjecaja sadržaja ljepila.

Ključne riječi: iverica, Salix viminalis, mehanička svojstva, sadržaj ljepila, gustoća

\footnotetext{
${ }^{1}$ Authors are assistant professors at Institute of Technology, Faculty of Mathematics, Physics and Technology, Kazimierz Wielki University in Bydgoszcz, Poland.

Autori su docenti Odjela za tehnologiju Fakulteta matematike, fizike i tehnologije, Sveučilište Kazimierz Wielki u Bydgoszczu, Poljska.
} 


\section{INTRODUCTION}

\section{UVOD}

One of the possible alternative raw materials in particleboard manufacturing can be fast growing shrubs of willow (Salix viminalis). They are cultivated in Poland for energy purposes, and their suitability for particleboard industry was confirmed by a number of studies (Frąckowiak, 2007; Frąckowiak et al., 2008; Warmbier et al., 2013, 2014a, 2014b). Sean and Labrecque (2006) found the usefulness of Quebec clones of this willow. Kowaluk and Fuczek (2010), and Kowaluk et al. (2008) used non-standard, specially prepared, particles from the willow (Salix viminalis). These particles, named fibrous chips, were produced on a Pallmann defibrator using a span of $1.2 \mathrm{~mm}$ between the hammer and milling disc. The authors showed the suitability of these particles for particleboard manufacturing.

Mechanical properties of particleboards depend on many factors, with the resin content and density of particleboard being the major ones. It is known that an increase in resin content and board density leads to improved mechanical properties of particleboards (Rackwitz 1963; Maloney 1993). However, the quantitative effects of these factors on the mechanical properties of particleboards made from willow (Salix viminalis) are not sufficiently known.

A typical particleboard for furniture purposes is a three-layer board, which consists of a core layer and two face layers. It was assumed that willow particles as a substitute for industrial wood particles would be used for manufacturing only the core layer. Therefore, it was decided to investigate a one-layer particleboard as simulating the core layer of a three-layer particleboard. The objective of this study was to evaluate the effects of resin content and board density on the mechanical properties of particleboards made from willow (Salix viminalis).

\section{MATERIALS AND METHODS} 2. MATERIJALI I METODE

Three-year-old stems of willow (Salix viminalis) with a diameter at the base ranging from 28 to $35 \mathrm{~mm}$ came from the Wielkopolska Region of Poland. The mean density of the stems was $0.51 \mathrm{~g} / \mathrm{cm}^{3}$ at a moisture content of $12 \%$, and bark percentage was about $15 \%$ of stem weight. The stems were chipped in a hammermill, and then screened by an analytical sieve shaker using $4 \mathrm{~mm}$ and $1 \mathrm{~mm}$ sieves. Particles that passed through the $4 \mathrm{~mm}$ sieve and remained on the $1 \mathrm{~mm}$ sieve were used as furnishes for experimental particleboards that simulated the core layer of three-layer particleboard. The bulk density of these particles was 0.20 $\mathrm{g} / \mathrm{cm}^{3}$. Prior to pressing, the particles were dried in an air-circulation oven to achieve a moisture content of less than $3 \%$.

Urea-formaldehyde (UF) resin was used as a binder. It had a density of $1.26 \mathrm{~g} / \mathrm{cm}^{3}$ at $60 \%$ solids, $\mathrm{pH}$ value of about 7 , a viscosity of $400-600 \mathrm{mPa} \cdot \mathrm{s}$ at $20^{\circ} \mathrm{C}$,
Table 1 Manufacturing parameters

Tablica 1. Parametri procesa proizvodnje ploča

\begin{tabular}{|l|c|}
\hline Parameter / Obilježje & Value / Vrijednost \\
\hline Board thickness / debljina ploče & $10 \mathrm{~mm}$ \\
\hline Board dimensions / dimenzije ploče & $40 \mathrm{~cm} \mathrm{x} 40 \mathrm{~cm}$ \\
\hline $\begin{array}{l}\text { Press temperature } \\
\text { temperatura prešanja }\end{array}$ & $180{ }^{\circ} \mathrm{C}$ \\
\hline Maximum pressure / maksimalni tlak & $2.5 \mathrm{MPa}$ \\
\hline $\begin{array}{l}\text { Press closing time } \\
\text { vrijeme zatvaranja preše }\end{array}$ & $25 \mathrm{~s}$ \\
\hline Pressing time / vrijeme prešanja & $3 \mathrm{~min}$ \\
\hline
\end{tabular}

and gel time of $40 \mathrm{~s}$ at $100{ }^{\circ} \mathrm{C}$. Three levels of resin content: 8,9 , and $10 \%$, and board density: 0.57, 0.60, and $0.63 \mathrm{~g} / \mathrm{cm}^{3}$, were assumed. The board manufacturing parameters are listed in Table 1. The particleboards were prepared in the laboratory. The target board thickness was $10 \mathrm{~mm}$. After spraying the adhesive on particles in a drum blender, a particleboard mat was manually formed inside a 40 × $40 \mathrm{~cm}$ box. The pressing conditions were the temperature of $180{ }^{\circ} \mathrm{C}$, maximum pressure of $2.5 \mathrm{MPa}$ and pressing time of $3 \mathrm{~min}$. Nine types of boards of different density and resin content were made. Four experimental boards were produced for each board type. The boards were not sanded.

Prior to testing, all the boards were stored in controlled conditions $\left(50 \%\right.$ relative humidity and $20{ }^{\circ} \mathrm{C}$ ) for two weeks. Test specimens were cut from the boards to determine the following mechanical properties according to appropriate EN standards: modulus of elasticity (MOE) and modulus of rupture (MOR) (EN 310, 1993), internal bond (IB) (EN 319, 1993), and screw-holding strength (SHS) (EN 13446, 2002) by using screws with a diameter of $3.5 \mathrm{~mm}$, length of $45 \mathrm{~mm}$ and a hole diameter of $2.5 \mathrm{~mm}$. Twenty specimens were prepared for each test and board type. Test specimens for IB and SHA were prepared from the specimens that were formerly tested for MOE and MOR.

The obtained data were statistically analyzed using the Statistica version 10. The analysis of variance (ANOVA) was conducted to determine the significance of the effects of resin content and board density on mechanical properties of particleboards.

\section{RESULTS}

\section{REZULTATI}

The results of the ANOVA test are shown in Table 2 . Both variables, resin content and board density, significantly affected the mechanical properties of particleboard. The interaction between the variables was not significant for each property.

The effects of board density and resin content on the mechanical properties of particleboards are shown in Figure 1. MOE and MOR increased with increasing board density and resin content. The increases in MOE and MOR, with increasing board density from 0.57 to $0.63 \mathrm{~g} / \mathrm{cm}^{3}$, were on average 18.5 and $29.2 \%$, respectively. The increases in MOE and MOR, with increasing resin content from 8 to $10 \%$, were on average 12.9 and $15.7 \%$, respectively. Thus, MOR was most af- 
Table 2 Two-way ANOVA test on the effects of resin content and board density on particleboard mechanical properties ( $p$-values)

Tablica 2. Dvosmjerni ANOVA test o utjecaju sadržaja ljepila i gustoće ploče na mehanička svojstva ploče iverice ( $p$-vrijednosti)

\begin{tabular}{|l|c|c|c|c|}
\hline $\begin{array}{l}\text { Variable } \\
\text { Varijabla }\end{array}$ & MOE & MOR & IB & SHS \\
\hline $\begin{array}{l}\text { resin content } \\
\text { sadržaj ljepila }\end{array}$ & $<0.0001^{*}$ & $<0.0001^{*}$ & $<0.0001^{*}$ & $<0.0001^{*}$ \\
\hline $\begin{array}{l}\text { board density } \\
\text { gustoća ploče }\end{array}$ & $<0.0001^{*}$ & $<0.0001^{*}$ & $0.0016^{*}$ & $0.0016^{*}$ \\
\hline $\begin{array}{l}\text { resin content x } \\
\text { board density } \\
\text { sadržaj ljepila } \\
\text { gustoća ploče }\end{array}$ & $0.9335^{\mathrm{ns}}$ & $0.9929^{\mathrm{ns}}$ & $0.9918^{\mathrm{ns}}$ & $0.9846^{\mathrm{ns}}$ \\
\hline
\end{tabular}

* Denotes significance at 0.01 / Označava signifikantnost pri $p=0,01$.

${ }^{\mathrm{n} s}$ Not significant at 0.05 / Nije signifikantno pri $p=0,05$.
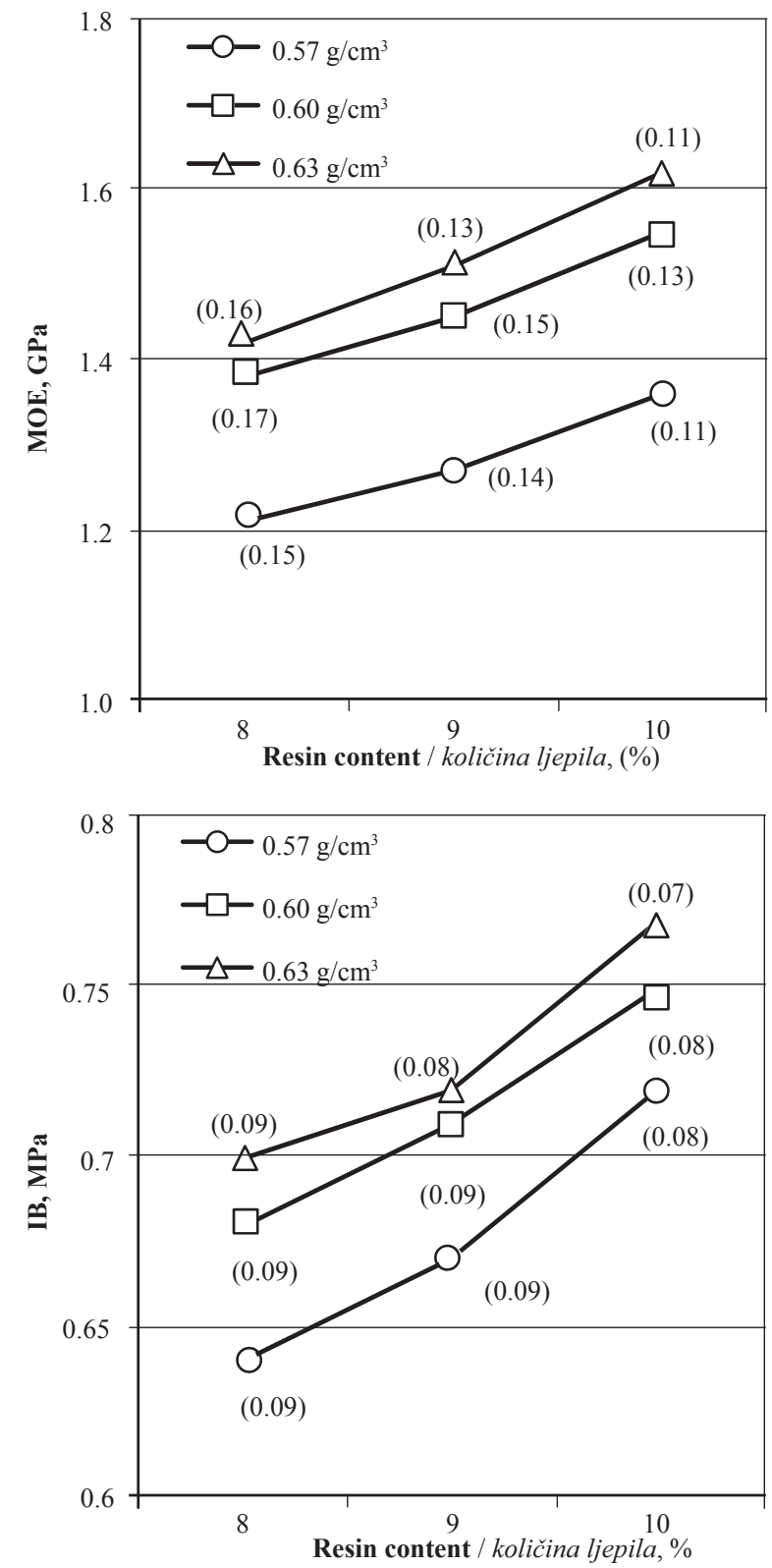

fected by increasing board density and resin content. Furthermore, the effect of board density was greater than that of resin content. It is worth mentioning that a relatively small increase in density of about $10 \%$ caused a much greater increase in MOE and MOR. These results can be explained by the fact that the increase in resin content caused more uniform coating particle surface by adhesive, and moreover that the increase in board density resulted in an increase in particle surface due to increasing wood compression (Rackwitz, 1963; Maloney, 1993). Similar effects of resin content on MOE and/or MOR of one-layer particleboards with UF resin as a binder were found in other studies: Papadopoulos et al. (2004) for particleboards made from bamboo (Bambusa vulgaris), with increasing resin content from 10 to $12 \%$; Zheng et al. (2006) for particleboards made from saline Athel tree (Tama-
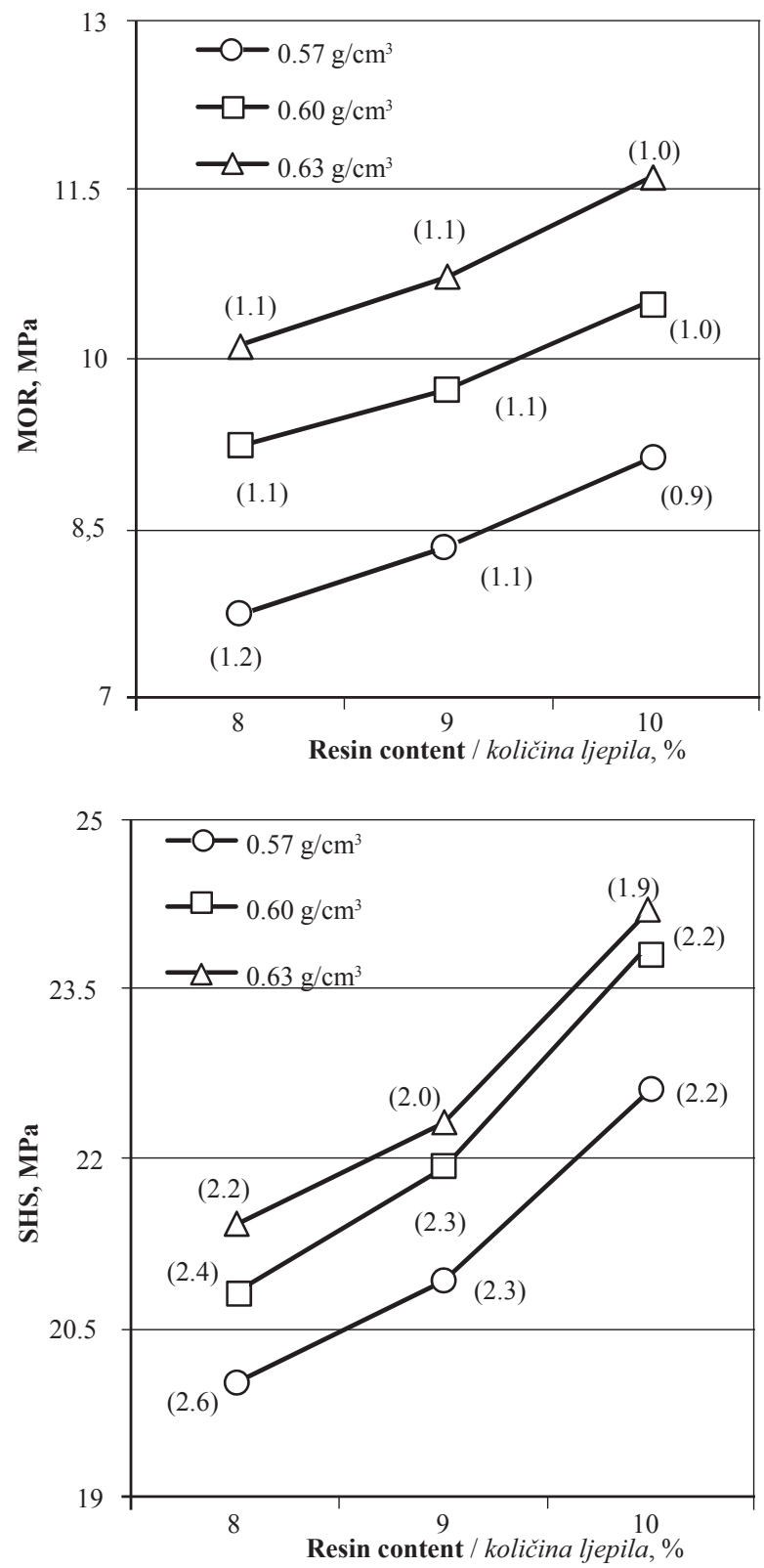

Figure 1 Effect of resin content on modulus of elasticity (MOE), modulus of rupture (MOR), internal bond (IB) and screw holding strength (SHS) of particleboards with different density (standard deviations in parentheses)

Slika 1. Utjecaj sadržaja ljepila na modul elastičnosti (MOE), modul loma (MOR), unutarnju čvrstoća vezanja (IB) i čvrstoću držanja vijaka (SHS) ploča iverica različite gustoće (u zagradama su navedene standardne devijacije) 
rix aphylla), with increasing resin content from 7 to 10 $\%$; Ashori et al. (2008) for particleboards made from date palm (Phoenix dactylifera), eucalyptus (Eucalyptus camaldulensis), mesquite (Prosopis juliflora) and saltcedar (Tamarix stricta), with increasing resin content from 9 to $11 \%$; Lin et al. (2008) for particleboards made from betel palm (Areca catechu), with increasing resin content from 8 to $10 \%$; Rathke et al. (2012) for particleboards made from poplar (Populus spp.) and locust (Robinia pseudoacacia), with increasing resin content from 7 to $8.4 \%$. Similar effects of board density on MOE and/or MOR of one-layer particleboards bonded with UF resin were found in other studies: Grigoriou (2000) for particleboards made from a mixture of straw and industrial wood particles, with increasing board density from 0.65 to $0.70 \mathrm{~g} / \mathrm{cm}^{3}$; Grigoriou and Ntalos (2001) for particleboards made from castor stalks (Ricinus communis), with increasing board density from 0.66 to $0.72 \mathrm{~g} / \mathrm{cm}^{3}$; Laemlaksakul (2010) for particleboards made from bamboo waste (Dendrocalamus asper), with increasing board density from 0.65 to $0.70 \mathrm{~g} / \mathrm{cm}^{3}$; Garcia-Ortuno et al. (2011) for particleboards made from giant reed (Arundo donax), with increasing board density from 0.69 to $0.74 \mathrm{~g} / \mathrm{cm}^{3}$.

The effects of board density and resin content on IB and SHS of particleboards are shown in Figure 1. IB and SHS increased with increasing board density and resin content. The increases in IB and SHS with increasing board density from 0.57 to $0.63 \mathrm{~g} / \mathrm{cm}^{3}$ were on average 7.9 and $6.9 \%$, respectively. The increases in IB and SHS with increasing resin content from 8 to 10 $\%$ were on average 11.0 and $13.7 \%$, respectively. Therefore, unlike the cases of MOE and MOR, the effect of board density on IB and SHS was less than that of resin content. The explanation of these increasing properties as a function of increasing board density and resin content is the same as for MOE and MOR. Similar positive effects of resin content or board density on IB and/or SHS were mentioned in previous studies: Grigoriou and Ntalos (2001) for particleboards made from castor stalks (Ricinus communis), with increasing board density from 0.66 to $0.72 \mathrm{~g} / \mathrm{cm}^{3}$; Zheng et al. (2006) for particleboards made from saline Athel tree (Tamarix aphylla), with increasing resin content from 7 to $10 \%$; Lin et al. (2008) for particleboards made from betel palm (Areca catechu), with increasing resin content from 8 to $10 \%$; Rathke et al. (2012) for particleboards made from poplar (Populus spp.) and locust (Robinia pseudoacacia), with increasing resin content from 7 to $8.4 \%$.

\section{CONCLUSIONS}

\section{ZAKLJUČAK}

One-layer experimental particleboards were manufactured from willow (Salix viminalis) as a substitute for industrial wood particles. Since the particleboards were to simulate the core layer of typical furniture threelayer particleboards, they were made from coarse particles of the size from 1 to $4 \mathrm{~mm}$. The board density and resin content, for their assumed ranges of variation, af- fected significantly the mechanical properties of particleboards. The modulus of elasticity (MOE), modulus of rupture (MOR), internal bond (IB) and screw holding strength (SHS) were determined. The effect of board density on MOE and MOR was greater than that of resin content, whereas the effect of board density on IB and SHS was less than that of resin content.

\section{REFERENCES}

\section{LITERATURA}

1. Ashori, A.; Nourbakhsh, A., 2008: Effect of press cycle time and resin content on physical and mechanical properties of particleboard panels made from the underutilized low-quality raw materials. Industrial Crops and Products, 28: 225-230.

http://dx.doi.org/10.1016/j.indcrop.2008.02.015.

2. Frąckowiak, I., 2007: Z badań nad wykorzystaniem alternatywnych surowców lignocelulozowych do produkcji płyt wiórowych. Technologia Drewna Wczoraj, Dziś i Jutro. Institute of Wood Technology, Poznań, Poland, 285-294.

3. Frąckowiak, I.; Fuczek, D.; Kowaluk, G., 2008: Impact of different lignocellulosic materials used in core of particleboard on modulus of elasticity and bending strength. Drewno-Wood, 51 (180): 5-13.

4. Garcia-Ortuno, T.; Andreu-Rodriguez, J.; FerrandezGarcia, M. T.; Ferrandez-Villena, M.; Ferrandez-Garcia, C. E., 2011: Evaluation of the physical and mechanical properties of particleboard made from reed (Arundo donax L.). BioResources, 6 (1): 477-486.

5. Grigoriou, A. H., 2000: Straw-wood composites bonded with various adhesive systems. Wood Science and Technology, 34: 355-365. http://dx.doi.org/10.1007/s002260000055.

6. Grigoriou, A. H.; Ntalos, G. A., 2001: The potential use of Ricinus communis (Castor) stalks as a lignocellulosic resource for particleboards. Industrial Crops and Products, 13: 209-218. http://dx.doi.org/10.1016/S0926-6690(00)00078-9.

7. Kowaluk, G.; Fuczek, D., 2010: Screw holding performance of panels made of fibrous chips. Drewno, 53: 7781.

8. Kowaluk, G.; Fuczek, D.; Beer, P.; Grzeskiewicz, M., 2008: Influence of the raw materials and production parameters on chosen standard properties for furniture panels of biocomposites from fibrous chips. BioResources, 6 (3): 3004-3018

9. Laemlaksakul, V., 2010: Physical and mechanical properties of particleboard from bamboo waste. World Academy of Science, Engineering and Technology, 64: 561565.

10. Lin, C. J.; Hiziroglu, S.; Kan, S. M.; Lai, H. W., 2008: Manufacturing particleboard panels from betel palm (Areca catechu Linn.). Journal of Materials Processing Technology, 197: 445-448. http://dx.doi.org/10.1016/j. jmatprotec.2007.06.048.

11. Maloney, T. M., 1993: Modern particleboard and dryprocess fiberboard manufacturing. Miller Freeman Publ, San Francisco.

12. Papadopoulos, A. N.; Hill, C. A. S.; Gkaraveli, A.; Ntalos, G. A.; Karastergiou, S. P., 2004: Bamboo chips (Bambusa vulgaris) as an alternative lignocellulosic raw material for particleboard manufacture. Holz als Rohund Werkstoff, 62: 36-39.

http://dx.doi.org/10.1007/s00107-003-0447-9. 
13. Rackwitz, G., 1963: Der Einfluss der Spanabmessungen auf einige Eigenschaften von Holzspanplatten. Holz als Roh- und Werkstoff, 21: 200-209. http://dx.doi.org/10.1007/BF02609724.

14. Rathke, J.; Sinn, G.; Harm, M.; Teischinger, A.; Weigl, M.; Müller, U., 2012: Effects of alternative raw materials and varying resin content on mechanical and fracture mechanical properties of particle board. BioResources, 7 (3): 2970-2985.

15. Sean, S. T.; Labrecque, M., 2006: Use of short-rotation coppice willow clones of Salix viminalis as furnish in panel production. Forest Products Journal, 56 (9): 47-52.

16. Warmbier, K.; Wilczyński, A.; Danecki, L., 2013: Properties of one-layer experimental particleboards from willow (Salix viminalis) and industrial wood particles. European Journal of Wood and Wood Products, 71: 25-28. http://dx.doi.org/10.1007/s00107-012-0650-7.

17. Warmbier, K.; Wilczyński, A.; Danecki, L., 2014a: Evaluation of mechanical and physical properties of particleboards with the core layer made from willow (Salix viminalis). BioResources, 9 (1): 894-905.

18. Warmbier, K.; Wilczyński, M.; Danecki, L., 2014b: Effects of some manufacturing parameters on mechanical properties of particleboards with the core layer made from willow (Salix viminalis). Annals of Warsaw University of Life Sciences. Forestry and Wood Technology, 88: 277-281.

19. Zheng, Y.; Pan, Z.; Zhang, R.; Jenkins, B. M.; Blunk, S., 2006: Properties of medium-density particleboard from saline Athel wood. Industrial Crops and Products, 23: 318-326. http://dx.doi.org/10.1016/j.indcrop.2005.09.003.

20. ***EN 310: 1993: Wood-based panels - Determination of modulus of elasticity in bending and of bending strength. European Committee for Standardization, Brussels-Belgium.

21. ***EN 319: 1993: Particleboards and fiberboards. Determination of tensile strength perpendicular to the plane of the board. European Committee for Standardization, Brussels, Belgium.

22. ***EN 13446: 2002: Wood-based panels - Determination of withdrawal capacity of fasteners. European Committee for Standardization, Brussels, Belgium.

\section{Corresponding address:}

\section{KRZYSZTOF WARMBIER Ph.D.}

Institute of Technology

Faculty of Mathematics, Physics and Technology

Kazimierz Wielki University in Bydgoszcz

Chodkiewicza 30

85-064 Bydgoszcz, POLAND

e-mail: warm@ukw.edu.pl 